\title{
Effect of surface modification by acetone vaporization on the structure of 3D printed acrylonitrile-butadiene- -styrene elements
}

\author{
Dawid Marciniak $\left.{ }^{1)}{ }^{*}\right)$, Piotr Szewczykowski ${ }^{1)}$, Piotr Czyżewski ${ }^{1)}$, Dariusz Sykutera ${ }^{1)}$, Marek Bieliński ${ }^{1)}$ \\ DOI: dx.doi.org/10.14314/polimery.2018.11.6
}

\begin{abstract}
The internal structure of samples produced by additive manufacturing (AM) technology of copolymer acrylonitrile-butadiene-styrene (ABS) was studied by microcomputer tomography (micro-CT). The results of micro-CT were correlated with the mechanical properties of samples. The aim of this paper was to demonstrate the acetone vaporization influence on the structure and mechanical properties of ABS samples printed with additive manufacturing technology. Samples were printed on three different devices and scanned with micro-CT after acetone vapors treatment. Mass and hardness of the samples were measured. Finally, the static tensile test was performed. Irregularly spaced voids, which directly affected samples properties, have been detected. Under the influence of acetone vaporization, the properties of the samples have changed such as: number of voids, mass, hardness, tensile strength.
\end{abstract}

Keywords: fused deposition modeling, microcomputer tomography, acetone vaporization, additive manufacturing, mechanical properties.

\section{Wpływ waporyzacji acetonowej powierzchni elementów wykonanych techniką 3D z kopolimeru akrylonitryl-butadien-styren na ich strukturę}

\begin{abstract}
Streszczenie: Strukturę wewnętrzną próbek wykonanych metodą technologii przyrostowej z kopolimeru akrylonitryl-butadien-styren (ABS) zbadano za pomocą mikrotomografu komputerowego (CT). Wyniki skanów CT skorelowano z właściwościami mechanicznymi próbek. Oceniano wpływ oddziaływania par acetonu na strukturę i właściwości próbek z ABS wykonanych w technologii przyrostowej. Próbki przygotowano z zastosowaniem trzech różnych urządzeń i po waporyzacji acetonowej zeskanowano je za pomocą mikrotomografu. Wyznaczono masę, twardość oraz przeprowadzono statyczną próbę rozciągania próbek. W strukturze elementów z ABS stwierdzono obecność nieregularnie rozmieszczonych porów, wpływających na właściwości próbek. Pod wpływem waporyzacji acetonowej zmieniły się właściwości próbek, takie jak: liczba porów, masa, twardość oraz wytrzymałość na rozciąganie.
\end{abstract}

Słowa kluczowe: osadzanie topionego materiału, mikrotomografia komputerowa, waporyzacja acetonowa, technologie przyrostowe, właściwości mechaniczne.

Acetone vaporization is one of the methods of improving the surface quality of 3D printed models made of acrylonitrile-butadiene-styrene (ABS) [1]. The surface smoothed by this method resembles the appearance of molded pieces obtained by injection molding technology [2]. Outer layer of a printed model becomes more even as a result of ABS being dissolved by acetone [3]. The evaluation of the internal structure, which for purpose of this paper is understood as a filament packing in a printed

\footnotetext{
1) UTP University of Science and Technology, Department of Materials Engineering and Polymer Processing, Institute of Manufacturing Technology, Al. Prof. S. Kaliskiego 7, 85-796 Bydgoszcz, Poland.

*) Author for correspondence:

e-mail: dawid.marciniak@utp.edu.pl
}

model, together with the effect of acetone on sample seems to be valuable data for the market and difficult to obtain without proper laboratory equipment. In order to meet the customers' expectations, companies are improving the surface quality of printed objects in various ways. Lacquering, resin coating, sandblasting, machining, polishing and above-mentioned acetone vaporization are some of the examples of 3D printed models surface treatment methods [4]. The post-production process can be as time-consuming, or even longer, as the model making process. The costs of surface finishing often can be also more expensive than 3D printed element itself, depending on model's purpose and customer's requirements [5]. Strength and weight of printed elements are crucial features, since there is a tendency to reduce the mass and increase strength of 3D printed elements simul- 
a)

b)

c)

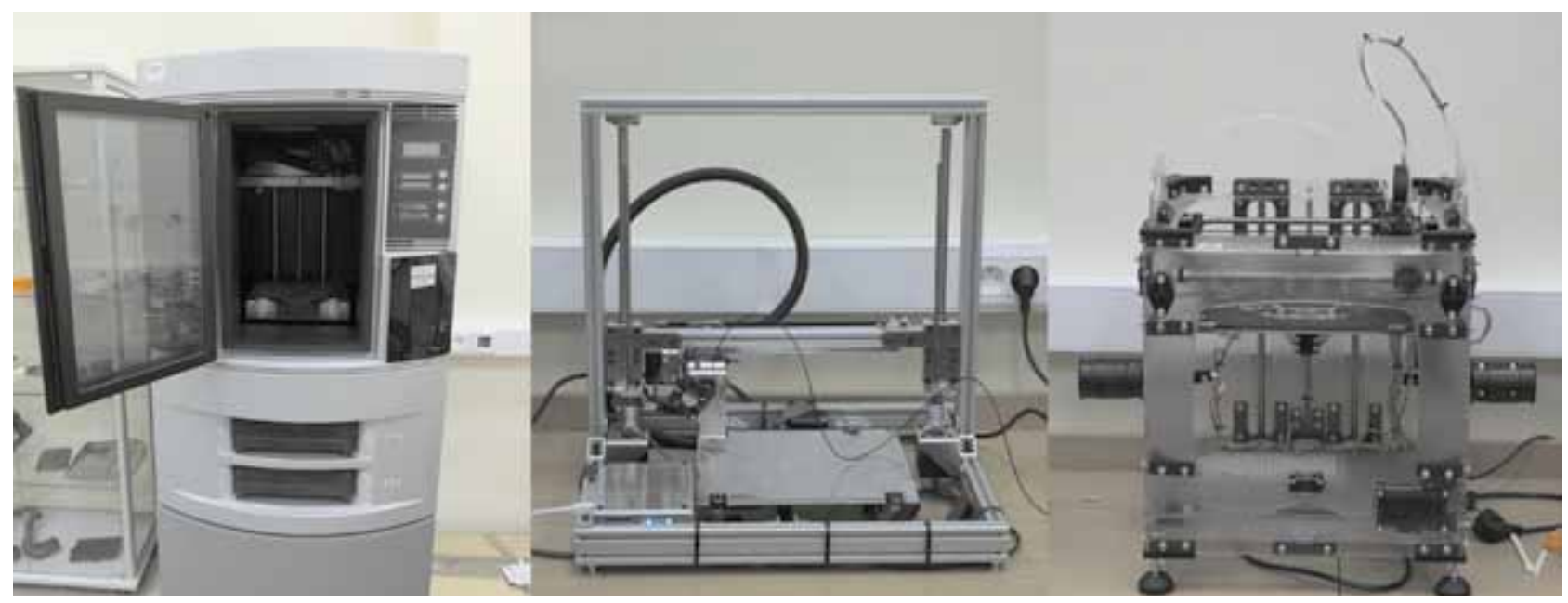

Fig. 1. 3D printers used for studies: a) Stratasys Dimensional Elite, b) 3Novatica Gate 1.0, c) Velleman Vertex K8400

taneously [6-9]. Those objectives can be achieve by applying expensive, sophisticated materials and by changing details geometry.

Internal structure, aging mechanism [10], stress corrosion [11] and properties of the material are crucial for the strength of the components made of polymers. Therefore, rapid prototyping techniques are useful for creating innovative products and its prototypes at low financial risk. They are also helpful during a transition phase between the project and serial production [12]. 3D models made by computer aided design (CAD) programs are the base for execution of the actual exemplar with rapid prototyping [13]. Fused deposition modeling (FDM) technology is one of the most popular rapid prototyping methods. Melted material is printed layer by layer to implement a designed form. It is expedient that printed models have the highest strength possible, so they can replace the original spare parts successfully [14]. ABS is one of the most commonly used material for printing prototypes. It is also broadly applied in the industry as a solid material for electronics, equipment enclosures, medical equipment [15], or automotive parts. Surface quality of prototypes made of ABS and polylactide (PLA) enhances by vaporization with acetone and tetrahydrofuran (THF), respectively [16]. The aim of this paper is to evaluate the internal structure of samples produced by additive manufacturing technology.

Studies have been conducted for the influence of acetone vaporization on the mechanical properties of ABS samples [17]. In these studies mass, hardness [18] and static tensile test of ABS samples exposed to acetone vapors were examined.

\section{EXPERIMENTAL PART}

\section{Sample preparation and 3D printing process specification}

The sample described as a type 5a accordingly to ISO 527 standard was used in research [19]. Samples were
T a b l e 1. Parameters of 3D printers

\begin{tabular}{|c|c|c|c|}
\hline Parameters & $\begin{array}{l}\text { Stratasys } \\
\text { Dimension } \\
\text { Elite }\end{array}$ & $\begin{array}{l}\text { 3Novatica } \\
\text { Gate }\end{array}$ & $\begin{array}{l}\text { Velleman } \\
\text { Vertex }\end{array}$ \\
\hline Nozzle diameter, mm & 0.30 & 0.50 & 0.35 \\
\hline $\begin{array}{l}\text { Temperature } \\
\text { of printing, }{ }^{\circ} \mathrm{C}\end{array}$ & 275 & 230 & 230 \\
\hline $\begin{array}{l}\text { Temperature } \\
\text { of heated bed, }{ }^{\circ} \mathrm{C}\end{array}$ & $\begin{array}{l}75 \text { (heated } \\
\text { chamber) }\end{array}$ & 95 & 23 \\
\hline $\begin{array}{l}\text { Speed of printing, } \\
\mathrm{mm} / \mathrm{s}\end{array}$ & Unknown & 40 & 40 \\
\hline Layer thickness, mm & 0.254 & 0.254 & 0.254 \\
\hline
\end{tabular}

manufactured by three different 3D printers: Stratasys Dimension Elite, 3Novatica Gate and Velleman Vertex K8400 (Fig. 1).

Material used for sample printing was $1.75 \mathrm{~mm} \mathrm{P430}$ ABS filament from Stratasys [20]. Constant conditions were provided for all tests [21]. Each of the machine had different nozzle diameter. In one of the 3D printers (Stratasys) higher temperature of printing was applied comparing to two others. Stratasys instrument was equipped in heated chamber while 3Novatica Gate was equipped in heated bed. Adhesive plate by BuildTak was used in Velleman Vertex model. Speed of printing was equal for two printers, while the speed for Stratasys machine was unknown. Layer thickness was the same for all printers. Printing parameters are summarized in Table 1.

\section{Acetone vaporization stand}

Acetone is highly flammable and harmful for health with boiling point at $57.1^{\circ} \mathrm{C}$. That is why samples were conditioned in the sealed chamber. Acetone is commonly used as a solvent and reacts very well with the ABS material [22]. Experimental stand is schematically presented in Fig. 2.

Four sample series with different acetone vapor exposure time were investigated. Each series contained 12 samples with 4 samples per printer. First series was the reference one with no exposure to acetone vapor. 


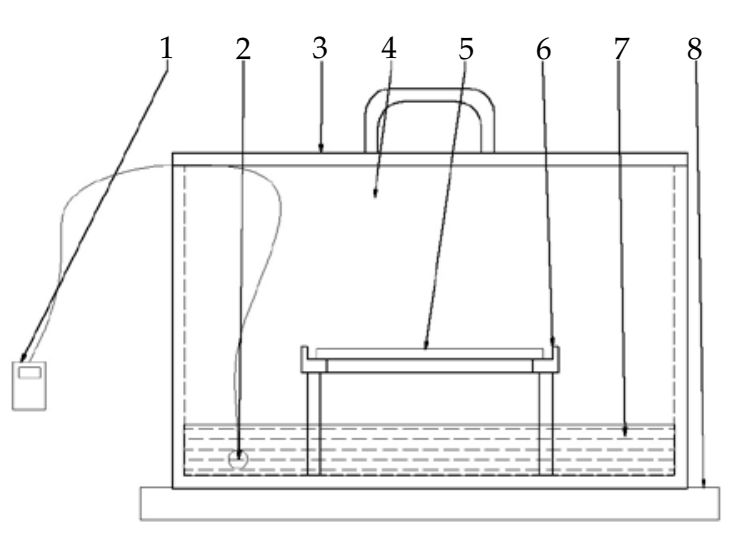

Fig. 2. Schematic diagram of acetone vaporization stand: 1 - thermometer, 2 - temperature sensor, 3 - lid, 4 - chamber, 5 - sample, 6 - stand for samples, 7 - acetone, 8 - heated plate

T a b l e 2. Description of parameters in each series

\begin{tabular}{c|c|c}
\hline Series & Exposure time, $\mathrm{s}$ & Temperature, ${ }^{\circ} \mathrm{C}$ \\
\hline 1 & 0 & 23 \\
2 & 10 & 70 \\
3 & 20 & 70 \\
4 & 30 & 70 \\
\hline
\end{tabular}

Table 2 presents exposure time and temperature of acetone vapors on particular series of samples. The temperature measured at the bottom of a chamber was $70{ }^{\circ} \mathrm{C}$.

\section{Methods of testing}

\section{Microcomputer tomography}

The equipment used for these studies was Bruker SkyScan 1272 with $75 \mathrm{~mm}$ maximum object size, 20$100 \mathrm{kV}$ maintenance-free X-ray source and 11Mp X-ray detector (14-bit cooled Charge Coupled Device optically coupled to scintilator). Scans parameters were the same for each sample: source voltage $50 \mathrm{kV}$, source current $200 \mu \mathrm{A}$, rotation step 0.2 degree, image pixel size $8 \mu \mathrm{m}$ and resolution $2016 \times 1344$ pixels. NRecon software was applied for 3D reconstruction, where ring artifact reduction and smoothing were at level 8 and 2, respectively. Beam-hardening correction was applied at a level of $30 \%$.

\section{Mass measurement}

Mass of dry printed samples was compared with mass of samples placed in the acetone vapors with different exposure time. Mass of vaporized samples was measured after $48 \mathrm{~h}$ since removal from acetone vaporization chamber.

\section{Hardness measurements}

Zwick 3106 hardness tester was used for hardness measurements by the push-ball testing method.
Measurements were done at $358 \mathrm{~N}$ load. The hardness measurements were conducted in accordance with ISO 2039-1 standard.

\section{Tensile tests}

The tensile strength test was conducted in accordance with ISO 527 standard at Zwick/Roell Z030 device.

\section{RESULTS AND DISCUSSION}

Micro-computed tomography (CT) is a non-destructive testing method, that allows to evaluate the interior structure of the samples. Figures 3 to 5 present scans of samples obtained by Stratasys, 3Novatica and Velleman printers, respectively. One can see some ring artifacts on presented CT pictures. The artifacts are minimized as much as possible by using the software. In general, those ring artifacts can be caused by some miscalibration of detector parts.

Scans have showed that samples made using the FDM technology have voids so the printed structure is weakened [23]. This is mostly visible for Stratasys Dimension Elite samples (Fig. 3), where one can observe the changes caused by the acetone vaporization. Acetone was penetrating the sample surface and dissolving print layers simultaneously closing the voids and smoothing the surface of the model. Samples obtained by 3Novatica machine (Fig. 4) have a lower dimensional tolerance and are more exposed to external factors. Printer Velleman maintained high accuracy of samples despite the lack of a heated bed (Fig. 5).

Table 3 summarizes the percentage of voids and average pore size in the samples depending on the acetone exposure time. The NRecon software reconstruction image were analyzed using CT Analyzer (CTAn) software. CTAn calculated the percentage of sample voids from 331 layers slice (thickness $2.64 \mathrm{~mm}$ ). As one can see samples are characterized by high interior heterogeneity and low repeatability. Decrease of voids inside the Stratasys samples after acetone vaporization was observed.

The longer acetone vapor exposure time the bigger decrease of voids inside ABS samples. For Stratasys samples that value decreased by $37.93 \%$ and for the 3Novatica and the Velleman samples decreased by $10.20 \%$ and $23.08 \%$, respectively. Dimension Elite device has high reproducibility of the printed models therefore it is more adapted to industrial applications. Irregularities detected in samples printed by other tested devices reflect their lower ability of projection and reproducibility.

Figure 6 shows average mass of the samples after acetone vapor treatment. For samples obtained by Stratasys printer mass decreased or was unchanged, while mass of the samples printed by 3Novatica increased significantly. Mass of samples printed by Velleman printer increased as well. Mass change could be caused by dissolution of the surface layer of model and saturation with acetone 


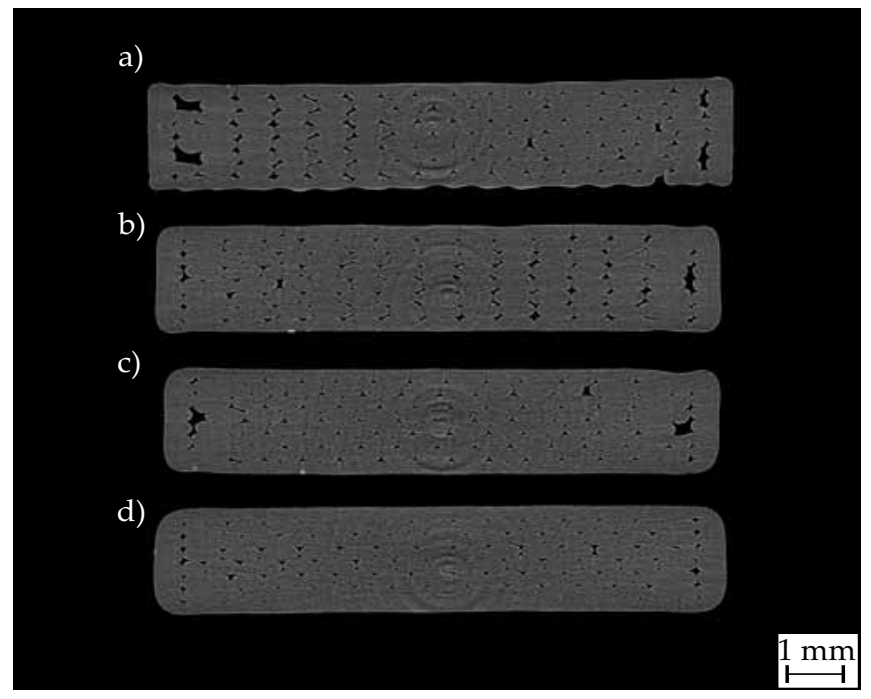

Fig. 3. Scans of samples from Stratasys printer exposed to acetone vapor at different time: a) $0 \mathrm{~s}$ (reference), b) $10 \mathrm{~s}, \mathrm{c}) 20 \mathrm{~s}$, d) $30 \mathrm{~s}$

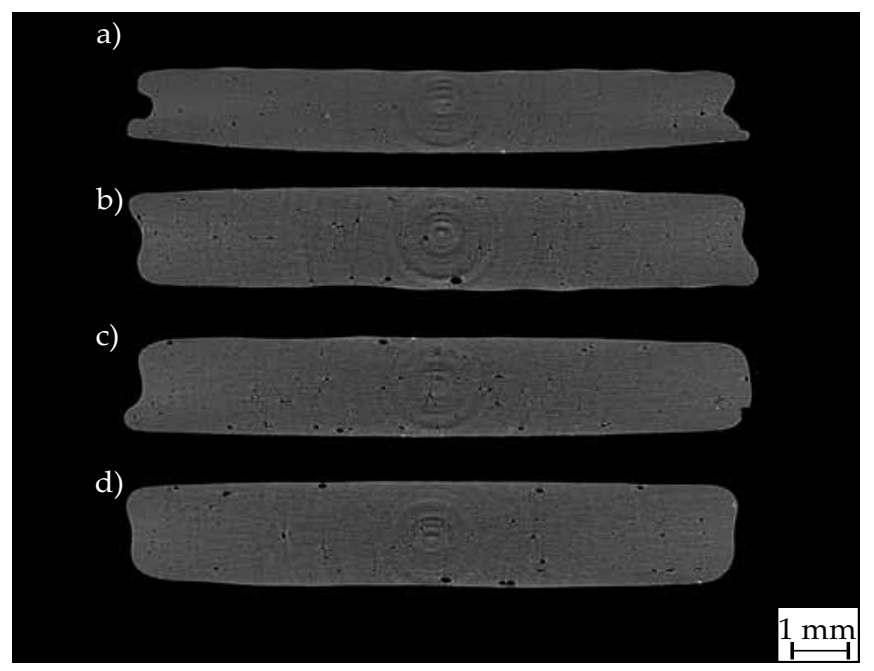

Fig. 4. Scans of samples from 3Novatica Gate printer exposed to acetone vapor at different time: a) $0 \mathrm{~s}$ (reference), b) $10 \mathrm{~s}$, c) $20 \mathrm{~s}$, d) $30 \mathrm{~s}$

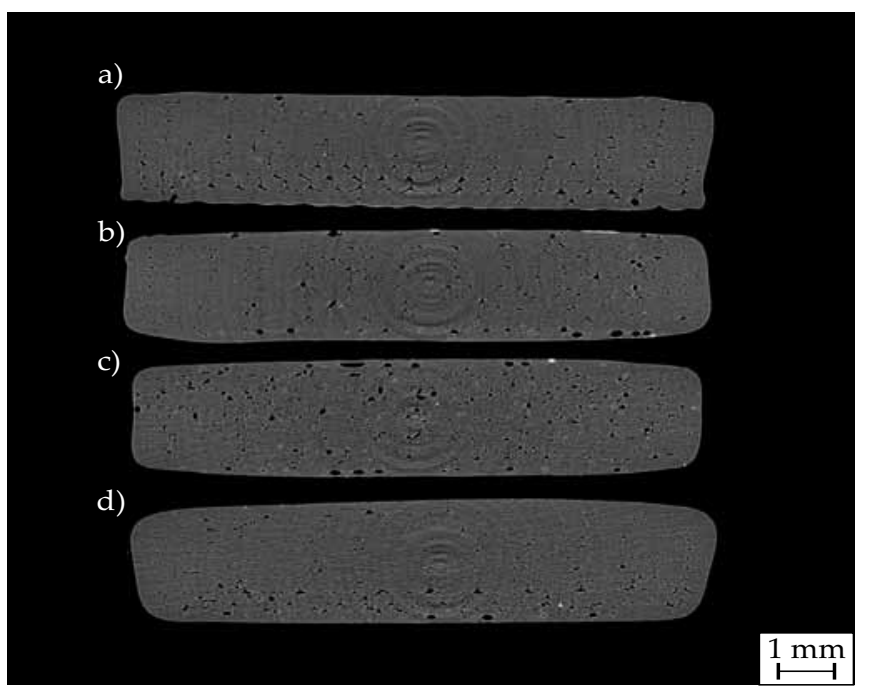

Fig. 5. Scans of samples from Velleman Vertex printer exposed to acetone vapor at different time: a) $0 \mathrm{~s}$ (reference), b) $10 \mathrm{~s}$, c) $20 \mathrm{~s}$, d) $30 \mathrm{~s}$
$\mathrm{T}$ a b 1 e 3. Percentage of voids and average pore size for samples printed by Stratasys Dimension Elite, 3Novatica Gate and Velleman Vertex printers

\begin{tabular}{l|c|c|c|c}
\hline \multicolumn{1}{c|}{ Indicator } & $\begin{array}{c}\text { Exposure } \\
\text { time, s }\end{array}$ & $\begin{array}{c}\text { Stratasys } \\
\text { Dimension } \\
\text { Elite }\end{array}$ & $\begin{array}{c}\text { 3Novatica } \\
\text { Gate }\end{array}$ & $\begin{array}{c}\text { Velleman } \\
\text { Vertex }\end{array}$ \\
\hline Voids inside & 10 & 1.45 & 0.49 & 1.04 \\
sample, \% & 20 & 1.12 & 0.54 & 0.64 \\
& 30 & 0.96 & 0.43 & 1.27 \\
Average & 0 & 0.28 & 0.84 & 0.41 \\
pore size, & 10 & 0.23 & 0.28 & 0.45 \\
mm $^{2}$ & 20 & 0.31 & 0.40 & 0.10 \\
& 30 & 0.16 & 0.27 & 0.16 \\
\hline
\end{tabular}

[24]. The largest increase in weight was observed in the samples with the longest exposure to vapors of acetone. Mass of Stratasys samples remained constant, while in the case of 3 Novatica and the Velleman samples their mass increased by $6.15 \%$ and $2.58 \%$, respectively.

In Fig. 7 one can notice that moderate acetone saturated samples are characterized by higher hardness. The hardness of the samples increased in the initial phase of acetone vaporization. After 10 seconds the model surface started to interact with the acetone, forming a thin reinforcing layer. In the subsequent stages hardness decreased. For Stratasys samples hardness increased by $13.88 \%$ after 10 seconds of acetone vaporization, 3Novatica samples gained $6.13 \%$ hardness to the reference samples, while for Velleman samples it was $14.05 \%$.

The tensile strength test was conducted in accordance with ISO 527 using Zwick/Roell Z030 device. Acetone vapors significantly reduced ABS samples strength (Fig. 8). The tensile strength decreased for the second and third series of samples and slightly increased for the fourth series in case of 3 Novatica and Velleman. Tensile strength of the researched ABS according to the producer is $31 \mathrm{MPa}$. Obtained results in each case were higher than those

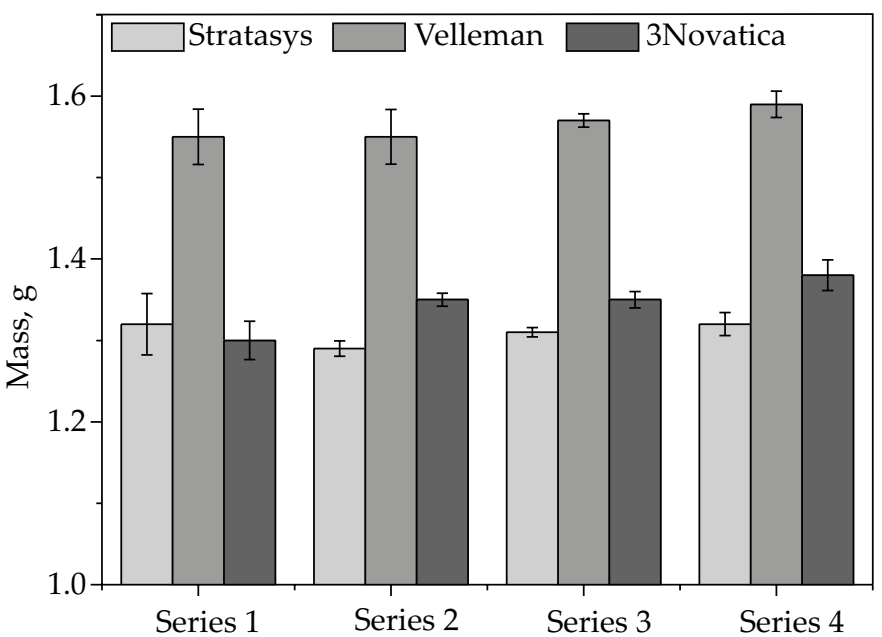

Fig. 6. Average mass of samples series after $0 \mathrm{~s}, 10 \mathrm{~s}, 20 \mathrm{~s}, 30 \mathrm{~s}$ acetone exposure time 


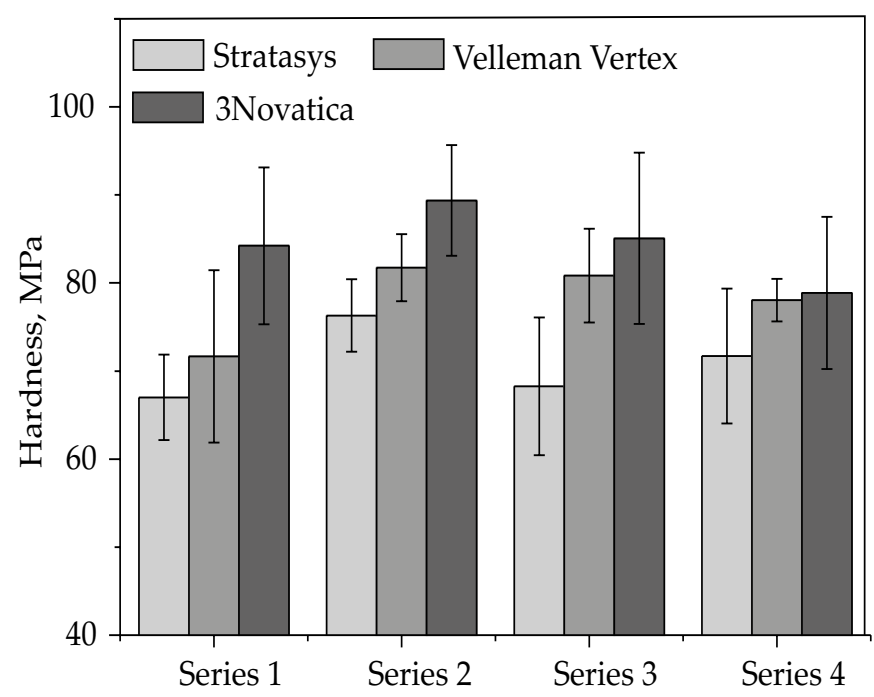

Fig. 7. Average hardness of samples series after $0 \mathrm{~s}, 10 \mathrm{~s}, 20 \mathrm{~s}, 30 \mathrm{~s}$ acetone exposure time

presented in the catalogs of filament producer. Tensile strength for Stratasys Dimension Elite samples decreased by $8.63 \%$. That could be caused by a larger amount of voids inside the samples. Tensile strength in the case of 3Novatica Gate samples increased by $9.32 \%$, and in the case of the Velleman Vertex by $0.04 \%$ [25].

\section{CONCLUSIONS}

Three different printers with similar parameters of $3 \mathrm{D}$ printing process were used to evaluate the quality of printed samples. Stratasys Dimension Elite had the highest repeatability of samples, the second was Velleman Vertex K8400, and 3Novatica Gate 1.0 printed the samples with the lowest quality. Different properties of printed samples could result from different nozzles diameter. The first printer generated $0.3 \mathrm{~mm}$ path of ABS, the second $-0.35 \mathrm{~mm}$, and the third one $-0.5 \mathrm{~mm}$. However it was not the aim of presented research, it was observed, that such external conditions as temperature fluctuations in a room or air convection had a significant impact on the 3D printing process and quality of samples. Increase of hardness of the samples exposed to vapors of acetone could be caused by dissolution of the surface layers of the samples. Mechanical properties were different due to the penetration of acetone into the structures of samples. The amount of voids decreased in printed elements as a result of partial dissolving of ABS by acetone. Hardness results may vary depending on the position of the indenter. Values will be much lower if the indenter fits between the filament paths. This phenomenon was observed only for reference samples (not vaporized). Samples after acetone vaporization had a thin coating of dissolved ABS and smooth surface. The tensile strength decreased after vaporization, which could result from the deterioration of the internal structure by acetone and from the formation of a coating surface layer by dissolved ABS.

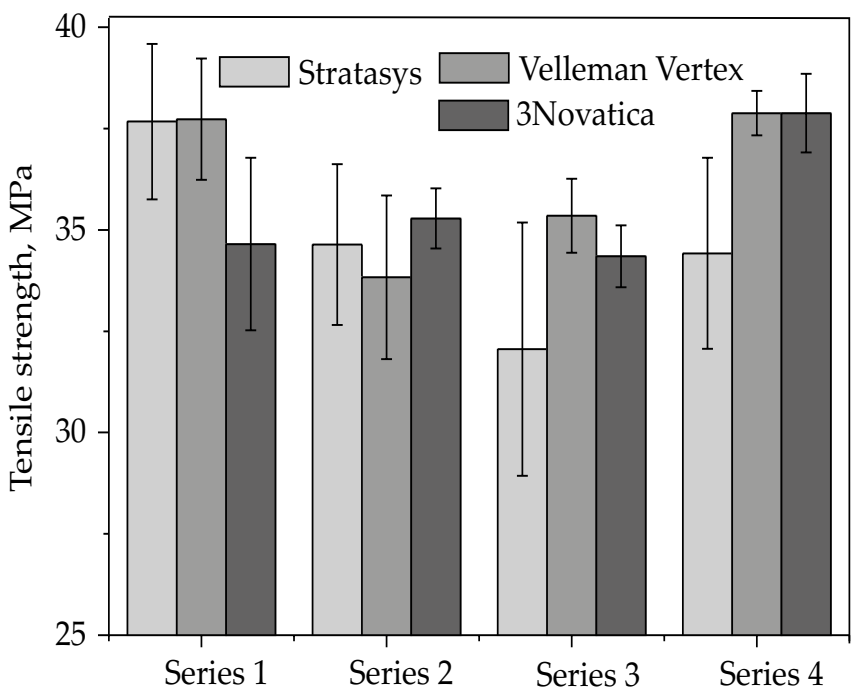

Fig. 8. Average tensile strength of samples series after $0 \mathrm{~s}, 10 \mathrm{~s}$, $20 \mathrm{~s}, 30 \mathrm{~s}$ acetone exposure time

\section{REFERENCES}

[1] Singh R., Singh S., Singh I.P. et al.: Composites Part B: Engineering 2017, 111, 228. http://dx.doi.org/10.1016/j.compositesb.2016.11.062

[2] Dawoud M., Taha I., Ebeid S.J.: Journal of Manufacturing Processes 2016, 21, 39. http://dx.doi.org/10.1016/j.jmapro.2015.11.002

[3] Pietanza S., Sorgente D., Percoco G.: Rapid Prototyping Journal 2015, 23, 5. https://doi.org/10.1108/RPJ-12-2015-0200

[4] Durgun I., Ertan R.: Rapid Prototyping Journal 2014, 20,3 .

http://dx.doi.org/10.1108/RPJ-10-2012-0091

[5] Zhang S.U., Han J., Kang H.W., Shin B.C.: “Thermomechanical properties of ABS parts fabricated by fused deposition modeling and vapor smoothing", Materials of $18^{\text {th }}$ International Conference on Thermal, Mechanical and Multi-Physics Simulation and Experiments in Microelectronics and Microsystems, 3-5 April 2017, Dresden, Germany. http://dx.doi.org/10.1109/EuroSimE.2017.7926222

[6] Vijay P., Danaiah P., Rajesh K.V.D.: Journal of Mechanical Engineering and Automation 2012, 1, 1. http://dx.doi.org/10.5923/j.jmea.20110101.03

[7] Onwubolu G., Rayegani F.: International Journal of Manufacturing Engineering 2014, ID 598531. http://dx.doi.org/10.1155/2014/598531

[8] Hossain M., Ramos J., Espalin D. et al.: Proceedings of 24th Annual International Solid Freeform Fabrication Symposium 2013, Austin, Texas, p. 380.

[9] Ziemian C., Cipoletti D., Ziemian S. et al.: Proceedings of 25th Annual International Solid Freeform Fabrication Symposium 2014, Austin, Texas, p. 525.

[10] Wąsicki A., Kościuszko A.: Polimery 2011, 56, 401.

[11] Bieliński M., Czyżewski P., Kościuszko A.: Polimery 2016, 61, 850. http://dx.doi.org/10.14314/polimery.2016.850 
[12] Lee B.H., Abdullah J., Khan Z.A.: Journal of Materials Processing Technology 2005, 169, 1. http://dx.doi.org/10.1016/j.jmatprotec.2005.02.259

[13] Armillotta A.: Rapid Prototyping Journal 2006, $12,1$. http://dx.doi.org/10.1108/13552540610637255

[14] Bakar N.A., Mohd R.A., Hambali B.: Journal of Zhejiang University - SCIENCE 2010, 11, 12.

[15] McCullough E.J., Yadavalli V.K.: Journal of Materials Processing Technology 2013, 213, 6. http://dx.doi.org/10.1016/j.jmatprotec.2012.12.015

[16] Bual G.S., Parlad K.: Manufacturing Science and Technology 2014, 2 (3), 51.

[17] Galantucci L.M., Lavecchia F., Percoco G.: CIRP Annals-Manufacturing Technology 2010, 59, 1.

[18] Singh R., Singh S., Singh I.P.: 3D Printing and Additive Manufacturing 2016, 3 (2). http://dx.doi.org/10.1089/3dp.2016.0001

[19] Durgun I., Rukiye E.: Rapid Prototyping Journal 2014, 20 (3), 228.
http://dx.doi.org/10.1108/RPJ-10-2012-0091

[20] Garg A., Bhattacharya A., Batish A.: The International Journal of Advanced Manufacturing Technology 2017, 89, 2175.

[21] Pepliński K., Czyżewski P., Górecki D. et al.: Polimery 2017, 62, 198.

http://dx.doi.org/10.14314/polimery.2017.198

[22] Kuo C.C., Mao R.C.: Materials and Manufacturing Processes 2016, 31, 8.

http://dx.doi.org/10.1080/10426914.2015.1090594

[23] Agarwala M.K., Jamalabad V.R., Langrana N.A. et al.: Rapid Prototyping Journal 1996, 2 (4), 4. http://dx.doi.org/10.1108/13552549610732034

[24] Percoco G., Lavecchia F., Galantucci L.M.: Research Journal of Applied Sciences, Engineering and Technology 2012, 4, 19.

[25] Perez T., Angel R., Roberson D.A., Wicker R.B.: Journal of Failure Analysis and Prevention 2014, 14, 3.

Received 5 II 2018. 